\title{
Village Level Provisioning Ecosystem Services and Their Values to Local Communities in the Peri-Urban Areas of Manila, The Philippines
}

\author{
Shamik Chakraborty ${ }^{1, *}$, Ram Avtar ${ }^{2,3} \mathbb{C}^{-}$, Raveena Raj ${ }^{3}$ and Huynh Vuong Thu Minh ${ }^{4}$ (i) \\ 1 Faculty of Sustainability Studies, Hosei University, 2-17-2 Fujimi Chiyoda-ku, Tokyo 102-8160, Japan \\ 2 Faculty of Environment Earth Science, Hokkaido University, Sapporo 060-0810, Japan; \\ ram@ees.hokudai.ac.jp \\ 3 Graduate School of Environmental Earth Science, Hokkaido University, Sapporo 060-0810, Japan; \\ rvraj_97@eis.hokudai.ac.jp \\ 4 Department of water resources, College of Environment and Natural Resources, Cantho University, \\ Cantho City 900000, Vietnam; hvtminh@ctu.edu.vn \\ * Correspondence: shamik.chakraborty.76@hosei.ac.jp; Tel.: +81-8083814924
}

Received: 30 September 2019; Accepted: 18 November 2019; Published: 20 November 2019

\begin{abstract}
This study investigates different provisioning services in the peri-urban landscapes of Manila conurbation through a case study of two villages in the Jala-Jala municipality of the Laguna de Bay area in the Philippines. Laguna de Bay is an ecologically productive and important watershed for the urban and peri-urban areas of Manila for the provision of food, freshwater, and other materials. However, the lake and its ecosystem are under threat because of rapid urbanization and associated land-use changes. This study is based on a semi-quantitative survey conducted with 90 households in two villages: Special District and Paalaman. It was aimed to capture how provisioning services in the locality are connected with local livelihoods. The results obtained from the study suggest that landscapes in this peri-urban area still has considerable provisioning ecosystem services associated with local biodiversity and that this dependence on provisioning services and their relationship to peri-urban landscapes and biodiversity should be addressed for sustainable landscape management. The results have important implications for the conservation potential of biodiversity on which local livelihoods depend, in urban and peri-urban ecosystems.
\end{abstract}

Keywords: ecosystem services; peri-urban areas; Laguna Lake basin; Paalaman; Jala-Jala; Likert scale

\section{Introduction}

Ecosystems provide multiple services to us with basic materials for survival and wellbeing such as food, fiber (e.g., cotton), and fuel (e.g., wood, charcoal). Ecosystems also provide other services that are less understood readily, such as storm surge defense by coral reefs and mangroves, which save human lives and properties. Also other intangible services such as providing good vista or other means through which we recreate and enjoy nature [1,2]. Ecosystems thus are related closely to our materialistic as well as non-materialistic (e.g., spiritual) wellbeing. Studies show that ecosystem services (ES) and human wellbeing are intricately related [3,4] and many of the wellbeing components may not be understood with simple monetary valuation only [5].

Sustainable use of biodiversity and ES in human-dominated landscapes such as urban and peri-urban areas is closely related to different human wellbeing components, such as health, security, and good social relations [6,7]. As more than two-third of the world population is expected to live in urban areas by 2050 [8], it is assumed that urban areas will have a bigger global ecological footprint $[9,10]$. However, urban areas depend on ecosystems to maintain a number of important 
wellbeing components through the release of different ES [11,12]. Urban areas-in order to remain sustainable-should be able to address the provision of ES for increasing human wellbeing in and around them $[13,14]$.

Peri-urban areas are urban fringe areas, characterized by rapid transition and interaction between the urban and the rural land uses. Peri-urban areas form important areas for conservation of biodiversity [15] and represent critical ecosystems where the natural structure, processes, and functions of the ecosystem are under pressure from urbanization, resulting in the decline of biodiversity and related ES $[12,16]$. This decline in biodiversity and ES can have adverse effects on food production and health that are related to human wellbeing $[17,18]$.

Peri-urban areas with interlinked human and ecological components can be regarded as socio-ecological systems $[19,20]$. For example, studies show that deterioration and/or decrease of urban and peri-urban home-gardens can deteriorate the species diversity [21]. Peri-urban areas can have important tangible benefits such as acquiring fuel-wood and housing materials [22], as well as intangible benefits such as aesthetic, recreational, and disaster mitigation services such as providing flood defense [23,24]. Considering ever-increasing urbanization and loss of ES as a consequence, urban and peri-urban planning and policy must include conservation and maintenance of diverse ES [25], and a bottom-up approach to protecting biodiversity and ES is vital in this sense [26].

Of recent, increasing demand for ES has become a prominent component in sustainable landscape management efforts $[11,14,27]$. ES and their connection to society are now recognized widely as a vital component for better human security, resilience, health, and choice of actions $[13,14,28]$. Among different ES (provisioning, regulating, supporting, and cultural), provisioning services are those that deal with material and energy output from the ecosystems and mainly consist of food, raw materials, water, and medicinal resources $[4,11,29,30]$. Like other ES, provisioning services are also closely linked with the biophysical structure, processes, and functions of an ecosystem [1,30]. There are studies that show that provisioning services can also be related to good mental and physical health conditions [31,32], leading to their influence on human cultural attributes as well. Provisioning services can thus become an essential tool for assessing the sustainability of landscapes in general including peri-urban areas.

In an attempt to address local community values on the importance of provisioning ES, the abundance of different provisioning ES, and their main drivers of change, this paper studies two peri-urban villages near Manila. The community's relation with ES has been assessed through the local community's perception on resources that are directly available from peri-urban village landscapes.

Studies in peri-urban landscapes of the global south show that peri-urban landscapes can be vital biodiversity conservation areas [33-40] giving us a chance to maintain and protect the numerous and unaccountable ES benefits biodiversity provides to mankind [27,41,42]. In the Philippines, the majority of the ES related studies include traditional rice-based systems and their watershed services [43-45], mangroves [46,47], and indigenous agriculture-based systems in ancestral land [48]. However, ES related studies on peri-urban areas remain understudied; although scattered literature in the Philippines argues for this issue e.g., Estoque and Maruyama [49].

\section{Study Area and Methods}

\subsection{Study Area}

The study covers two villages, Special District and Paalaman in Jala-Jala municipality in the province of Rizal (Figure 1). Jala-Jala municipality covers about $44 \mathrm{~km}^{2}$ peninsular type of land that juts into the shallow Laguna Lake. It is the eighth largest municipality in Rizal province in terms of land area. Jala-Jala is situated about $70 \mathrm{~km}$ to the east of Manila conurbation. The municipality is about $55 \mathrm{~km}$ away from Pasig city (capital of the Province of Rizal), the nearest urban area adjacent to Manila (Figure 2). 


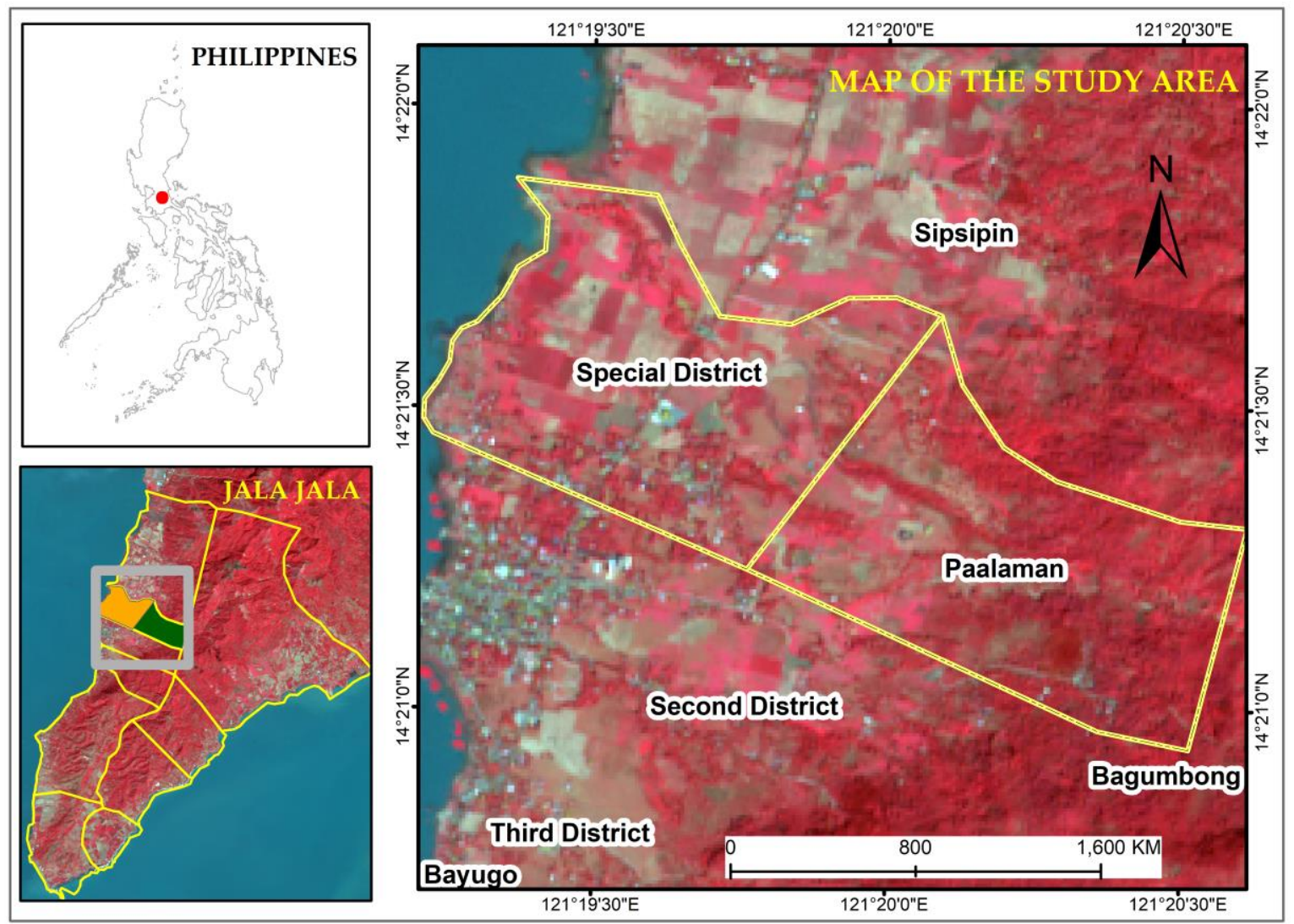

Figure 1. Location of Laguna de Bay Basin and the study areas.

The municipality forms a part of the peri-urban areas around Manila and a part of Laguna de Bay ecoregion. The Laguna de Bay ecoregion is affected by the urbanization of Manila conurbation. This urbanization has led to pollution of water bodies, alteration of the flow regime of the tributary rivers of the Laguna Lake (Figure 2) by structural adjustments, increasing built-up areas and croplands, all of which have combined to deteriorate the watershed environments of the region [50], deteriorating resilience of the urban and peri-urban ecosystems.

The urban and peri-urban areas of Manila are situated within Laguna de Bay watershed, which is one of the largest lagoons in Asia. It is an ecologically productive urban lake basin in the Philippines and a part of the complex Pasig-Marikina-Laguna de Bay Watershed. Its ecosystem creates a brackish water environment maintained by saltwater and freshwater pulses. The lake basin is drained by 24 tributary rivers, the waters of which flows through the lake and the Pasig River to the Manila Bay. Thus, the system consists of a watershed with an annular or concentric drainage pattern with only one outlet (through the Pasig River). The lake waters are replenished in approximately 8 months, because of a large amount of freshwater input from the surrounding watershed [50]. The tributary watershed landscapes (such as the area studied in this paper) carry out important ecosystem functions of the lake ecosystem, carrying water, soil, and nutrients that support biodiversity in the lake basin [51].

Laguna de Bay ecosystem has been a vital source of multiple ES. People use the lakeshore and riverine areas for harvesting fish, clams, snails, wild game, firewood, and vegetation. Indigenous fish species such as goby (Gobiopterus lacustris), tigerperch (Leiopotherapon plumbeus), needle fish (Zenarchopterus philippinus), and Manila sea catfish (Arius manillensis Valenciennes) found in the area are also nationally threatened [52]. The habitats of nationally threatened species indicate that important ecosystems, albeit in a fragile state, are present in the area. The watershed also houses a wide variety of crustaceans, mollusks, and indigenous plants [53]. The ecosystem thus constitutes a vital natural resource base for the urban and peri-urban landscapes of Manila. 


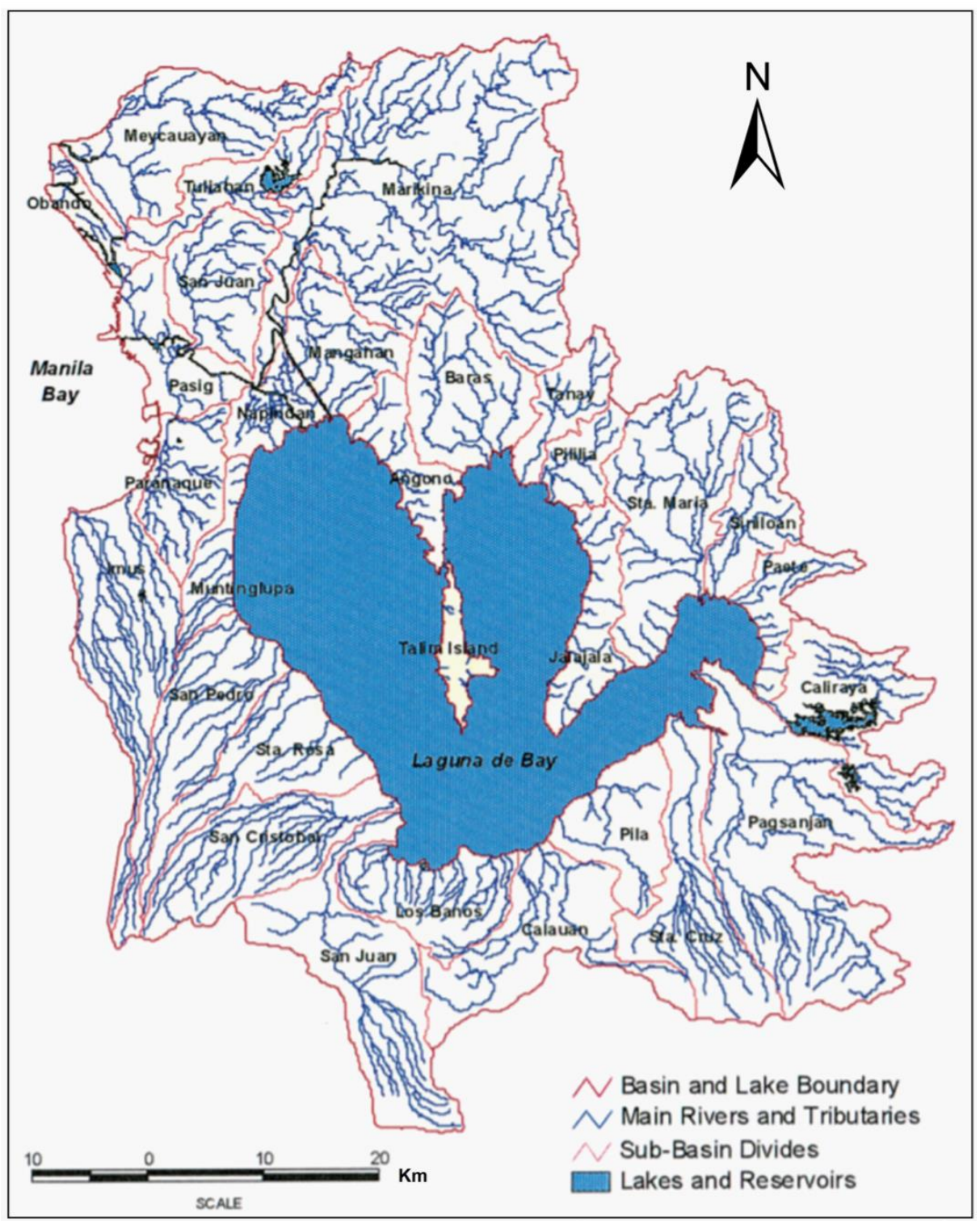

Figure 2. Location of the municipalities of the tributary rivers of the Laguna de Bay $[54,55]$.

The two villages (Special District and Paalaman) are chosen for this study in order to capture the picture of provisioning services at the village level (Figure 1). The Jala-Jala municipality was selected because of its diverse landscapes (i.e., availability of grasslands, brushlands ${ }^{1}$, built-up areas, agricultural areas) (Figure 3). The Jala-Jala area is also reported to be a relatively biodiverse area situated near the Manila conurbation with farming and fishing-based populace who depend on their surrounding landscapes for livelihoods. The situation of low-lying lagoon area with fertile soil and coupled with monsoon climate has produced the biodiverse characteristic of the Jala-Jala. Jala-Jala is covered with regenerative forests (brushlands) and home-gardens and lakeshore settlements with fishing and agriculture-based communities. These brushlands are remnants of forests that were felled by logging companies in the 1950s and 1960s. The opening of brushlands (regenerative forests) often takes place with an increase in fallow lands or grasslands, which occupy the ecologically vacant

1 Brushlands denote the degraded forest areas as a result of extensive logging that took place in the Laguna de Bay basin after the World War. However, although they denote a "degraded" state regarding the initial forest cover, they are also the "regenerative" and post extraction secondary type forests, except where they are altered further to non-forest areas. 
spaces [56]. It is worth noting that regenerative forests are the largest and the most dynamic type of forest ecosystem in the Philippines [57]. These forests are under threat from land use change in watersheds primarily consisting of agricultural expansion, artificial reforestation, and logging [58], their future in the peri-urban areas thus are especially vulnerable.

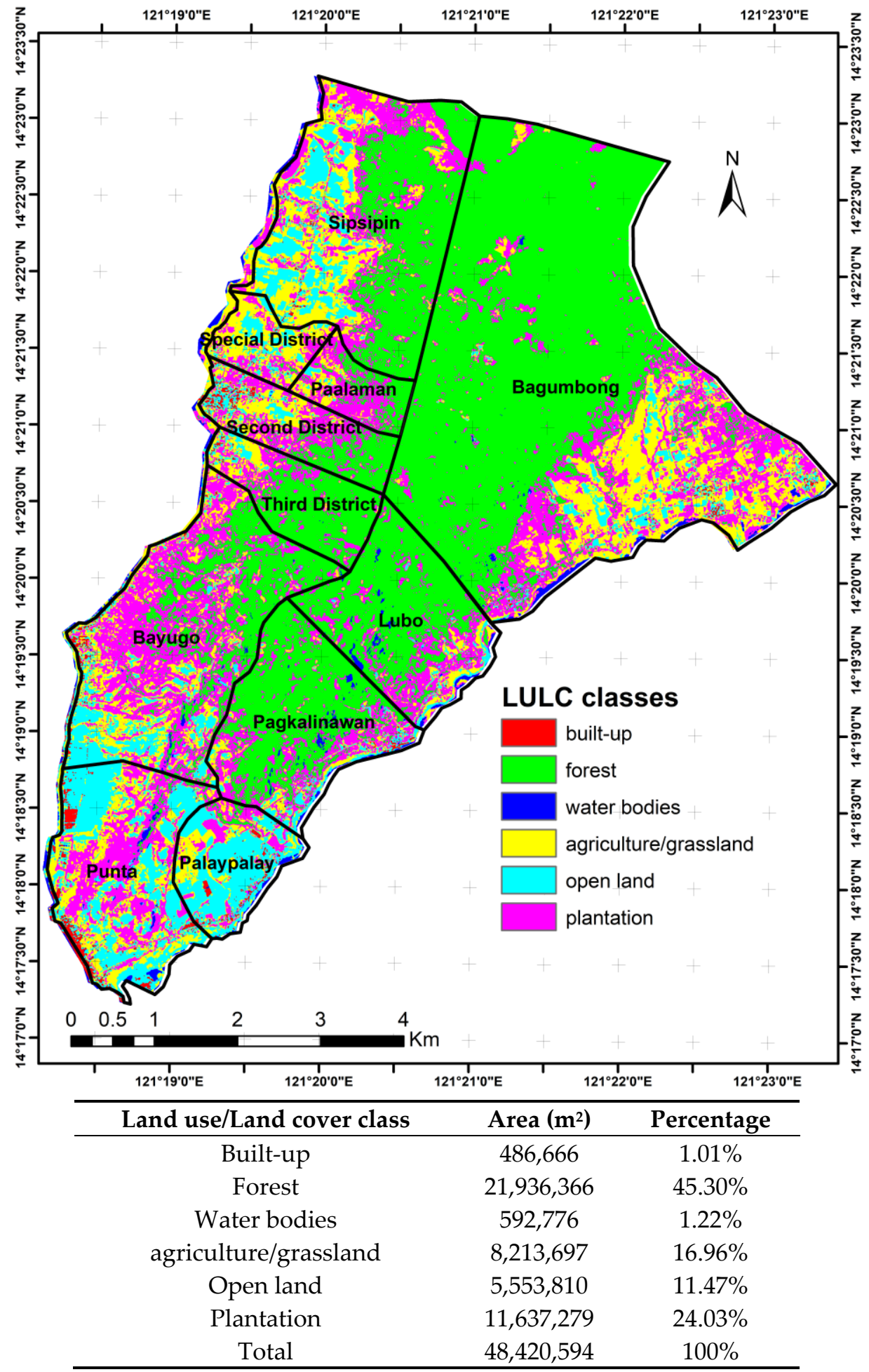

Figure 3. Land use land cover map of Jala-Jala peninsula. 


\subsection{Methods}

The study carried out a survey conducted between May and September 2016 with both male (38 in Special District and 47 in Paalaman) and female (42 in Special District and 48 in Paalaman) heads of 90 households (Table 1). A semi-quantitative survey was conducted using a Likert scale because we needed to capture locals' perception on provisioning services through social valuation techniques. The data were represented through descriptive statistics to visualize the obtained information quantitatively. The aim of the survey was to assess local community values on the importance of provisioning services, the abundance of different provisioning services, and their main drivers of change. A comparison of the economic situation between the villages and the relation to ES were also carried out in the study to find out how provisioning services are related with locals' economic situation and how these services are used in the two villages. We interviewed both the main male and female resource harvesters/users in each household. So, there were 80 respondents from Special District and 95 from Paalaman, resulting in a total of 175 respondents (42 households from special District and 48 households from Paalaman) to the survey (Table 2). As of 2015, Special District had a total population of 4196, and Paalaman had a total population of 343 [59]. Landscapes were divided into two categories, which are: (a) Those near the lakeshore regions represented by the village Special District; (b) those inland and away from the lakeshore regions represented by the village Paalaman to capture and compare the different provisioning services available in these two types of landscapes. The surveyed population in the two villages was characterized by low income, farmers, fishers, and small business owners of various ages, with low education levels.

Table 1. Explanation of data for analysis.

\begin{tabular}{|c|c|c|}
\hline Analysis & Methods & Describes \\
\hline $\begin{array}{l}\text { 1. Identification of different } \\
\text { provisioning services, quantification }\end{array}$ & $\begin{array}{c}\text { Face to face household questionnaire } \\
(\mathrm{N}=90) \text { in areas inland and areas near } \\
\text { lakeshore }\end{array}$ & \multirow{3}{*}{$\begin{array}{l}\text { Provisioning services from } \\
\text { peri-urban areas }\end{array}$} \\
\hline 2. Villages covered & $\begin{array}{l}\text { Jala-Jala: Special District, Paalaman } \\
\qquad(\mathrm{N}=90)\end{array}$ & \\
\hline 3. Main interviewees & Farmers, fishermen, local businessmen & \\
\hline
\end{tabular}

The survey was conducted with the permission of local barangay captains through a written letter of request by the first author of the article. The survey was done with training and instructions to local researchers, together with an expert in rural and urban studies in the Philippines. A local researcher from Manila in order to break the language barrier and engage better with the local communities conducted the actual survey.

For ES analysis we sought people who were engaged with subsistence level resource use as a part of their livelihood. This is because forms of subsistence were an important parameter to judge the connection of people to the ecosystem at the landscape level. However, because of the influence of urban processes in the study areas, the subjects were not solely dependent on subsistence living. We approached the resource user community by asking them to describe what kinds of resources they directly acquire from the surrounding areas (for example, agricultural areas, home-gardens, degraded forests, riparian areas, freshwater streams, and the Laguna Lake).

A snowball sampling procedure was followed, where each level of household interviewees introduced the researchers to the next target households. The participants were selected through two local key informants who were well acquainted with the Jala-Jala landscape and local people. Key informants, together with households also helped us find families who lived in the areas for more than 30 years to acquire long term livelihood-based information on local landscapes. The number of subsequent households ranged between 1 to 4 , depending on the previous interviewees' willingness, as well as on their acquaintance level with other families. Snowball sampling was applied, as the 
main goal of the study was primarily exploratory and descriptive (e.g., the values attached by locals to different provisioning services which they acquired from the target landscape, the drivers of change of these ES as experienced by the locals), where this type of sampling works well [60]. Snowball sampling technique was used to go deeper into the population regarding their everyday resource use from the landscapes, a socio-ecological part that lay hidden and needs special methods (e.g., acquaintances) to extract data.

Table 2. Socioeconomic profile of the survey.

\begin{tabular}{|c|c|c|}
\hline Socioeconomic Profiles & Special District & Paalaman \\
\hline Total Households surveyed & 42 & 48 \\
\hline Men & 38 & 47 \\
\hline Women & 42 & 48 \\
\hline Total Respondents & 80 & 95 \\
\hline \multicolumn{3}{|c|}{ Age structure of respondents } \\
\hline$<20$ & 2 & 3 \\
\hline $20-40$ & 26 & 16 \\
\hline $41-60$ & 45 & 58 \\
\hline$>60$ & 7 & 18 \\
\hline \multicolumn{3}{|c|}{ Main employment of the household } \\
\hline Fisher & 29 & 19 \\
\hline Business & 6 & 14 \\
\hline Farmer & 4 & 7 \\
\hline Unemployed & 3 & 8 \\
\hline \multicolumn{3}{|c|}{ Average income (in thousand PHP) } \\
\hline$<10$ & 21 & 31 \\
\hline 10 to 20 & 17 & 11 \\
\hline 21 to 30 & 4 & 3 \\
\hline 31 to 40 & 0 & 2 \\
\hline$>40$ & 0 & 1 \\
\hline \multicolumn{3}{|c|}{ Highest educational Level in the household } \\
\hline Elementary graduate & 27 & 31 \\
\hline Middle school graduate & 5 & 6 \\
\hline High school graduate & 7 & 11 \\
\hline No education & 27 & 31 \\
\hline
\end{tabular}

Based on the response of the local resource users, a five-point Likert scale expressed the degree of importance given to the set of ES [61]. We created a list of provisioning ES and assess their importance to the locals. This type of socio-cultural perception study is increasing and becoming more in use in ES oriented studies [11]. The respondents were asked to choose from a 5-point scale- "Very important," "Important," "So-so," "Less important," "Not important," with "Do not know" as an additional option.

During the survey, the interviewees were also asked to choose a set of most important drivers of change to the provisioning services. The survey tried to capture the perception of the local resource users and identify factors which deteriorate provisioning services. Local resource users often have a greater understanding of provisioning services than understanding of regulating, supporting, and cultural ES. Thus, the procedure followed in the survey gave clarity of perception in identifying the drivers of change when compared with other ES.

The survey was terminated when the information asked for started to repeat them, taking this as an indication of saturation point [61]. In our case, the survey was continued up to 90 respondents. The acquired data were then represented through descriptive statistics. 


\section{Results and Discussion}

\subsection{Multiple Provisioning Services from Peri-Urban Village Landscapes}

Our study found that a total of 10 provisioning services were available from the two villages. These were: crops, firewood, timber, non-timber forest products (NTFPs) such as fruits and honey, livestock, freshwater, game, fish, shellfish and clams, and medicinal plants that the local populace acquired from the surrounding landscapes, rivulets, creeks, canals and the lake (Figure 4). Fishing was the major source of income in the surveyed households, as 48 of the 90 households (53\%) in the studied villages depended on a fisheries-related profession. The availability of NTFPs from plants that providing wild food and medicines, as well as their importance in the local households in a crop and fisheries based local economy was particularly important that showed the characteristic of provisioning service in the two villages. Fruits, wild herbs and medicinal resources acquired free from the landscapes constituted the main part of the plant-based NTFPs. The availability of wild game such as monitor lizards, wild boars, wildcats, pythons, game birds such as jungle fowls, herons, orioles, and quails mentioned during the interviews mean that the area is supportive to wild animals at the vicinity of the lakeshore areas. The most widely hunted species were reticulated python, and red jungle fowl. Paalaman households showed a higher frequency of hunting wild animals than the Special District.

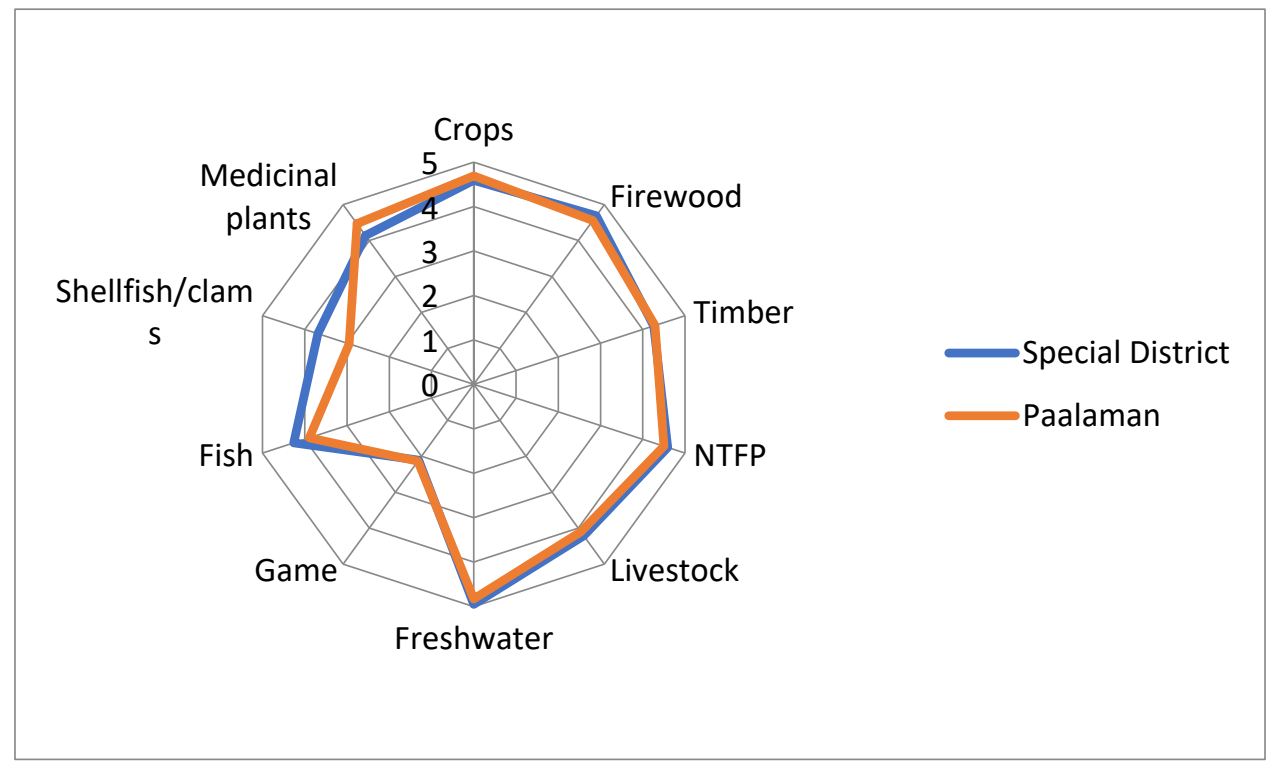

Figure 4. Average importance of different ecosystem services for each household $(\mathrm{N}=90)$ in the two villages (Special District and Paalaman).

Our study obtained a similar picture of importance values attached to provisioning services in general by the households of the two villages. However, households of Paalaman showed slightly higher importance values attached to crops, timber, game, and medicinal plants and slightly lower importance values attached to firewood, NTFP, livestock, freshwater, fish, and shellfish and clams when compared to that of Special District (Figure 4). The surveyed households depended on 15 types of fish, clams, and snails in their diet. This indicates the availability of diverse food provisioning for a total of $59(66 \%)$ households in the two villages (32 households in Special District and 27 households in Paalaman). The poorer population also consumed invasive species like the kuhol snails (Pomacea) that are damaging especially to the rice plants. Cultured tilapia (Perciformes) and freshwater clams (Corbiculafluminea) were the major fish and clams consumed in the two villages. Forest products were used in 38 (42\%) households, and crops were used by 35 (39\%) households in the two villages. 
Land areas that were not exactly near the lakeshore cultivated 34 crop varieties, whereas lakeshore areas (available only in Special District) cultivated 5 crop varieties with an overabundance of water spinach (Ipomoea aquatica); along with collecting firewood (also used in charcoal-making), medicinal plants, and hunting of small game animals. Natural medicines were acquired from 19 different varieties of plants near the village domain (some of these were also cultivated in the agricultural plots). Paalaman's households acquired more medicinal plants than that of Special District because of its nearness to the forested areas of Jala-Jala. The most widely used medicinal plants were moringa (Moringaoleifera), bitter gourd (Momordicacharantia), stone breaker (Phyllanthusniruri), oregano (Origanumvulgare), aloe vera (Aloe barbadensis Mill), ashitaba (Angelica keiskei), and leichhardt tree (Naucleaorientalis). Fruits acquired free from the surrounding landscapes constituted another well mentioned NTFP. Food therefore, marked some of the most ubiquitous provisioning services acquired from the landscape, a fact also observed by other studies [62], together with medicinal plants. Freshwater from natural springs was regarded as a very important provisioning service by $40(44 \%)$ households in Special District and 42 $(47 \%)$ households in Paalaman. Freshwater available through springs act not only as provisioning but also vital supporting service because of their link to groundwater environments [63].

One characteristic feature of the study was that the provisioning services were related to diverse landscapes of the two villages through local livelihoods (e.g., agricultural areas, home-gardens, degraded forests, riparian areas, freshwater streams, and the Laguna Lake). The benefits from provisioning services in this sense (goods and services available from the diverse landscapes for free), together with the biophysical structure and processes that produce them remains to be a significant economic asset to be considered for future land use policymaking in the region.

Moreover, judging from the average monthly income from our survey, we found that local resource users in our study in both the villages had similar kind of socioeconomic situations. However, Paalaman had slightly poorer households as 31 of 48 households (about 66\%) lived below PHP 10,000 per month compared to 21 of 42 households (50\%) in Special District. About $59 \%$ of the surveyed households, mostly consisting of farmers, fishers, and small business owners, earned less than 10,000 $\mathrm{PHP}^{2}$ per family (average 9438 PHP). The lower-income level in the two villages showed that a considerable portion of the relatively economically poorer households relied on the "free" provisioning services from these diverse landscapes (Figure 5).

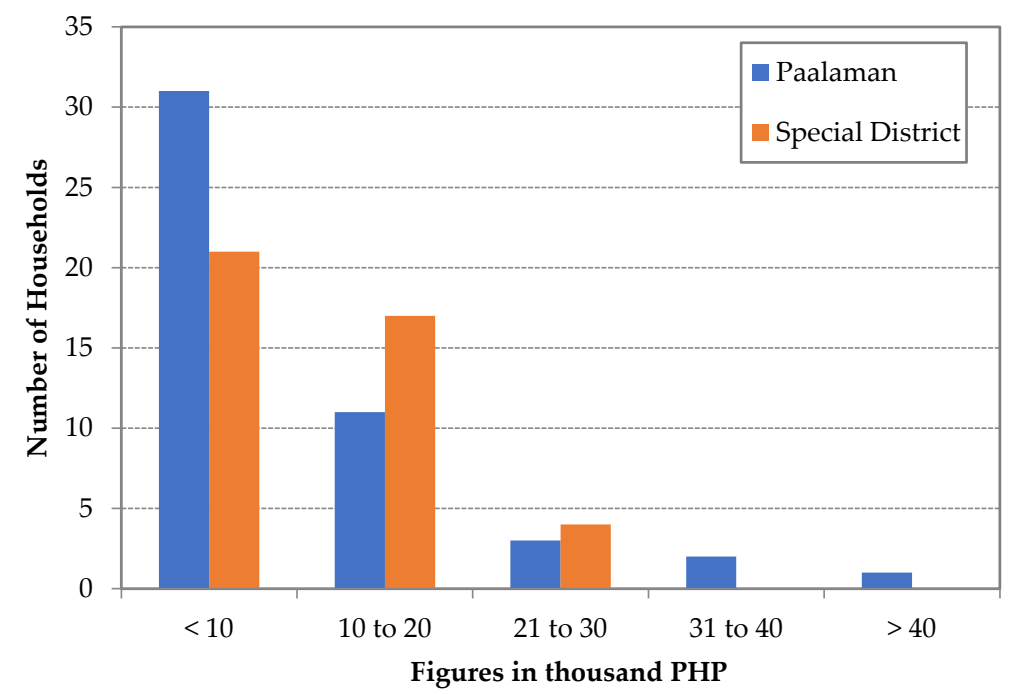

Figure 5. Percentage of average monthly income in the surveyed households $(\mathrm{N}=90)$.

$2 \quad \mathrm{PHP}=$ Philippine Pesos (1 peso means approximately 0.020 USD) 
Several scholars have studied the importance of diverse landscapes for keeping landscape ecological integrity from a species based inquiry [64] or an inquiry-based on land use and land cover changes $[64,65]$. Our study shows that the relationship of provisioning services with livelihoods can be a valid way to capture the importance of diverse landscapes to the livelihoods of the locals. Our findings are in line with works of [66-69] and our results show high importance of local resource harvesters with the direct provisioning services acquired from different types of landscapes (e.g., agricultural areas, home-gardens, degraded forests, riparian areas, freshwater streams, and the Laguna Lake). Based on the findings we argue that this assessment of ecosystems' linkage to the livelihoods is not stressed on in the previous studies as well as in the land-use decision-making in the Philippines. Such human components are an asset of peri-urban areas including that of Manila. Livelihood-based studies like this are necessary for keeping the diversity of peri-urban ES and their functions to be systematized in an easily understandable manner. This systematization is needed for the conservation of a diverse pattern of local resource use that is functionally related to biodiversity conservation and socio-economic wellbeing near urban and peri-urban landscapes. Moreover, we can add here that although open lands, fallow lands, and grasslands denote further degradation of regenerative forests, these landscapes nevertheless house diverse types of resource use and this indicates that degraded forest areas should be paid more attention for conservation, given, as our study suggests, the bundle of provisioning services they are still capable of producing.

\subsection{Unique Challenges Faced in the Case Study}

This study of the two villages shows the existence of vertebrates that are linked to provisioning through hunting; although hunting is becoming rarer as a practice with the dwindling vertebrate population in the area (an issue raised by the respondents). Studies suggest that globally, $10 \%$ of the terrestrial vertebrates are found in the ecoregions near urban and peri-urban areas, which comprise only $0.3 \%$ of the earth's land surface [70]. This has considerable implications for their conservation, even in near urban areas, and careful consideration is needed whether hunting activities can still be allowed in the area. Especially the existence of carnivores such as civet cat (Viverratangalunga), a reticulated python (Python reticulatus), and monitor lizard (Varanussalvador) is an important facet of biodiversity near the urban areas, as these species form the top of the food chain and cannot survive without a population of prey animals. Wild pigs found in Jala-Jala are a vulnerable species in the Philippines; the Philippine warty pig has been designated as an endemic and vulnerable or threatened animal on the IUCN red list [71].

During the survey, abiotic resources such as natural springs as drinking water sources, and fertile soil were deemed important because of their direct influence on provisioning services. Hydrological disasters such as floods were seen to have a negative influence on the use of the landscape. Flooding from the river and the increase in the areal extent of the lake were seen as a negative factor for cultivation in the land. This shows that locals do not realize the beneficial effects of natural flooding. This can be a cause of worry, as tributary streams in the watershed are vulnerable to the building of more artificial levees and flood prevention mechanisms in the future; that may result in deterioration of lateral, longitudinal, vertical, and temporal connectivity in streams, eventually affecting the provisioning ES form the landscapes. As physical connectivity maintains and restores the flow of energy, matter, and organisms in the landscape [72-75]; such developments can lead to degradation of multiple ES that are still found in these areas; a concern raised by other scholars [76]. Floods also provide natural disturbance regimes that are needed for the resilience of the ecosystem [77,78]. Provisioning services that depend on natural pulsed changes such as floods in the ecosystem, therefore, need to be addressed on a special basis apart from the day-to-day needs of local populations. Likewise, releasing fish fry and increasing aquaculture in the lake can eventually result in degrading some ecosystem services in the lake ecosystem such as small-scale local fisheries, and a decline in the population of indigenous fish species. Although it is argued that aquaculture can be helpful in reducing the harvesting pressure in wild species, it can degrade local biodiversity if practiced without restrictions $[79,80]$. 


\subsection{Drivers and Pressures of Changes of Provisioning Services in the Watershed}

A total of 11 interlinked drivers (direct and indirect) were identified through the direct experiences of the locals. The direct drivers were: climatic variation, natural disasters, land use change, invasive species, overexploitation, not adapted management, and pollution, whereas indirect drivers were: demographic, socio-economic, political, and science and technology. Moreover, some of the direct drivers of ecosystem change discussed above (namely overexploitation, not adapted management, and pollution) have been the outcome of the indirect drivers [13,81]; these direct drivers can thus also be explained as pressures that directly change the ecosystem. These direct and indirect drivers affected 6 to 9 provisioning services in our study. Climatic variations and invasive species were two of the most mentioned drivers but were linked to three types of provisioning services (crops, livestock, and fish), while not adapted management was linked to only one provisioning service (decrease of medicinal plants due to weeding). Several factors mentioned during the survey were related to the process of urbanized land use in the rural area of Jala-Jala. These were: increase in residential areas and siltation of rivers due to increase in construction materials in the streams (e.g., cement, sand), water pollution from increasing pig farming and household wastes from a rapidly increasing population in the lakeshore areas, and a high amount of fish cages that try to maximize fish output to be sold for consumption in Manila, while adversely affecting the livelihoods of small-scale local fishers. These factors were repeatedly mentioned during our survey as an effect of the increasing pressure from the consumption pattern of Manila's populace on the landscape we studied, putting adverse impacts on the multiple provisioning services the area is still capable of supporting local livelihoods.

Additional interviews in the villages suggested that more effort in livestock production as a special local environmental problem (such as pig farming, which degrades local freshwater sources and the shore-lands of Laguna Lake through effluent discharges) and less effort in the production of crops from diverse landscapes in the villages. This was mentioned as a major problem for the future of Jala-Jala's agricultural landscapes in general as well. Thus, livestock production, although included as a vital ES in our study, can degrade remaining grasslands and brush-land areas in the study area and can see an increase of one ES (livestock production) at the expense of other multiple ES.

Figure 6 shows how the different drivers are related to the importance attached by the local resource users. We see that multiple drivers of change affect highly important provisioning services for the locals in the two villages (Table 3). The number of drivers of change affecting different provisioning services remains the same in the two villages. Both for Special District and Paalaman, fish, crops, water, and timber are affected by a higher number of drivers of change ( 5 to 7 drivers) than NTFPs, medicinal plants, firewood and livestock (3 to 4 drivers). Special District shows important provisioning services provided by shellfish and clams are affected by 6 different drivers of change. It is assumed that the involvement of more number of different drivers affecting a particular provisioning ES means the increase of threat to that ES. Also, the multiple drivers indicate the unpredictability and complexity involved with changes associated with the ES [82,83].

Table 3. Drivers of change of different provisioning services available in the two villages.

\begin{tabular}{|c|c|c|c|}
\hline $\begin{array}{c}\text { Different ES and Their Color } \\
\text { Codes }\end{array}$ & $\begin{array}{l}\text { Number of } \\
\text { Drivers }\end{array}$ & Specific Drivers & $\begin{array}{c}\text { Legend for Drivers of } \\
\text { Change }\end{array}$ \\
\hline Crops & 5 & $A, B, E, F, G$ & A - Demographic \\
\hline Firewood & 3 & A, B, I & B - Socioeconomic \\
\hline Timber & 6 & $A, B, C, D, G, I$ & C - Political \\
\hline NTFP (fruits, mushrooms, honey) & 4 & B, D, G, I & D - Science \& Technology \\
\hline Livestock & 3 & $\mathrm{~A}, \mathrm{~B}, \mathrm{E}$ & E - Climatic variation \\
\hline Freshwater & 7 & $\mathrm{~A}, \mathrm{~B}, \mathrm{C}, \mathrm{D}, \mathrm{G}, \mathrm{I}, \mathrm{K}$ & F - Natural disaster \\
\hline Game & 5 & A, B, D, G, I & G - Land use change \\
\hline Fish & 7 & A, B, D, G, H, I, K & $\mathrm{H}$ - Invasive species \\
\hline Shellfish/clams & 6 & A, D, G, H, I, K & I - Overexploitation \\
\hline Medicinal plants & 3 & $A, G, J$ & $\begin{array}{c}\text { J - Not adapted management } \\
\text { K - Pollution }\end{array}$ \\
\hline
\end{tabular}




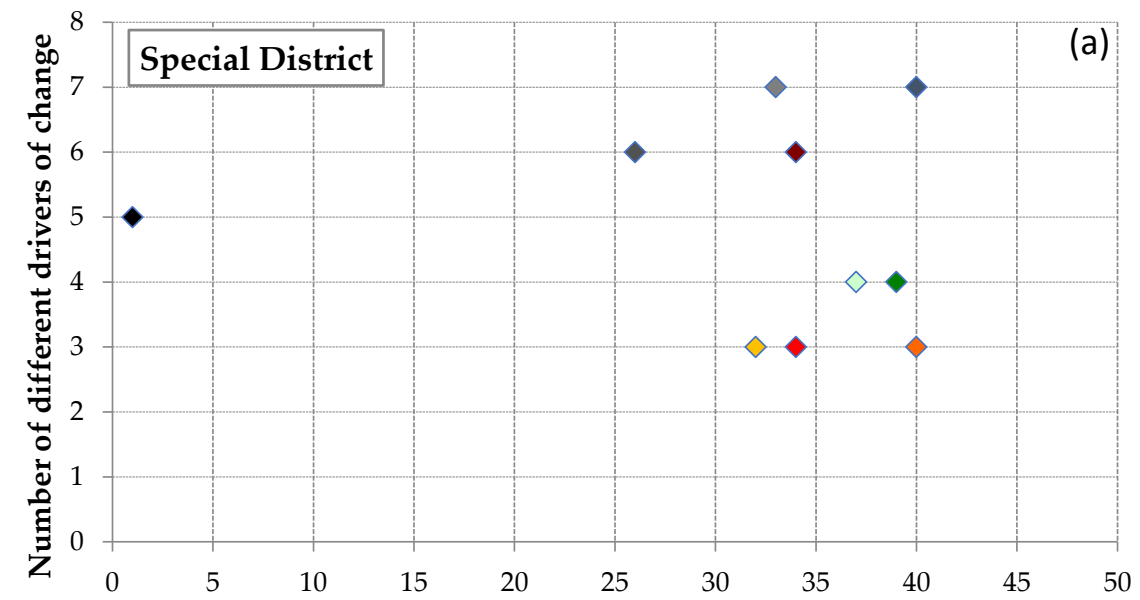

Number of households rendering "very important" and "important"

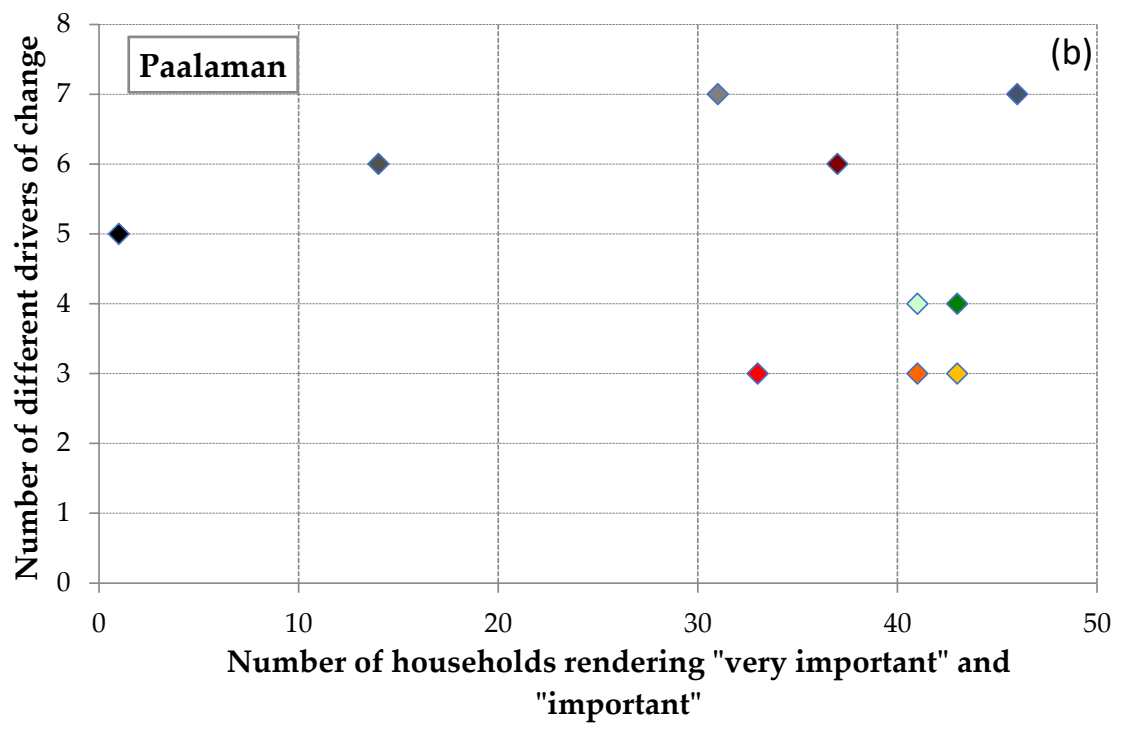

Figure 6. The relation between drivers of change and importance values attached to ecosystem services (ES) by local resource users in the two villages, (a) Special district $(\mathrm{N}=42)$ and (b) Paalaman $(\mathrm{N}=48)$. The colors denote different provisioning services (See Table 3 for details).

By looking at the relation of the "drivers" and the "importance," policymakers and ES-based landscape managers will have a better idea for what services need urgent action for their future conservation in the area (i.e., by concentration on the upper right quadrant of Figure 6). Less important services such as acquiring wild game, shellfish and clams, with high to moderate number of drivers affecting them also needs special attention, as it means diversity of fauna from the landscape are at very high risk due to lack of understanding of their functions in maintaining different provisioning services and may become nonexistent in the future.

\subsection{Policy Implications and Towards Pathways for Conservation}

Through our case study, we provide two interlinked recommendations for policy and practice in the case study area. These recommendations also apply for the overall management of peri-urban landscapes of the Laguna Lake basin. While these recommendations are context-specific, as they are based on local resident's perceptions, they nevertheless can be applied to peri-urban areas where livelihood-based and socio-ecologically sound development is sought after. Two specific recommendations are: 
- Restoration and maintenance of peri-urban watershed environment depend on restoring the social-ecological relationships in the peri-urban landscape. Our results, through a case study of provisioning services, show that in order to achieve sustainable development in urban and peri-urban areas, local ES needs to be incorporated into land-use planning. This is indicated by the finding that the two villages in Jala-Jala entail a considerable diversity of resource use that in turn provides multiple benefits from the ecosystems for the local population. It is thus desirable that present accounting systems try to include this value of direct provisioning to the local communities to reduce the domino effect of the ever-expanding urbanization and/or land use changes such as sweeping mono-culture of cultured fisheries that feed urban areas.

- Mixed livelihood and agricultural practices in the lowlands of the tributary watersheds are supported by multiple provisioning services that still exist in degraded and fragmented agricultural and brush-land landscapes around Manila. It is therefore recommended that while planning from village levels, tributary watersheds be given adequate conservation measures for basin management with an ES approach. Moreover, it is reasonable to maintain and restore such mixed agricultural and brush-land landscapes in other parts of the Philippines as well to maintain the natural capital they possess for the balanced development in these areas.

In relation to the conservation spaces within production landscapes, the balance between aggrading and degrading areas needs to be considered. For example, ES available in landscapes like Jala-Jala are based on movements of biomass (food, fiber, fuel, etc.) across and beyond (but not excluding) the immediate landscapes. Such wilder landscape elements present in the agricultural areas, remain essential parameter to address for landscape conservation [84].

\subsection{Limitations of the Study}

One limitation of the study was the sampling technique we used in the study. Purposive and non-representative sampling was followed. The sampling method made the study subjective toward decision and understanding of the local resource users as the participants were chosen purposefully through snowball sampling. Snowball sampling also made it not possible to test any hypothesis regarding the population studied, as we analyzed the results through descriptive statistics. Therefore, other (non-purposive) sampling procedure that can draw inferences regarding the population can be a better choice if a correlation study is targeted. Although, we would like to add here that purposive sampling is useful in studying hidden information in the study area such as the relationship of the local population with the biodiversity around them, which our study was supposed to reveal.

In this paper, we have primarily focused on the "inventorying" of main provisioning services. We recognize that more research is needed that brings this overall picture, and relations between different ES in the peri-urban livelihoods of Manila, so that landscape of ecological value becomes well embedded in the peri-urban land use policies. It is expected that the importance of different provisioning services, as well as the status of their degradation, will be even more prominent if more spatial samples can be taken from the Laguna Lake basin as well as other areas in the Philippines with urban proximity.

\section{Conclusions}

Our study conducted a semi-quantitative survey to identify diverse provisioning services from two villages in Jala-Jala Municipality in Rizal, Philippines. The study through this survey brings out local community values on the importance of provisioning services, the abundance of different provisioning services, and their main drivers of change. Our results suggest that local provisioning services play an important role in the livelihoods of the two villages studied. The main provisioning services that were important for the locals in both the villages in general were freshwater, crops, firewood, timber, NTFPs, livestock. Fish, shellfish and clams were more important in Special District, while medicinal plants had slightly higher importance value in Paalaman than in Special District. 
All these were related to the wellbeing of the local community through multiple tangible services. These provisioning services also supported the relatively poorer population in the two villages.

The survey also revealed the threats to these provisioning services by a number of interlinked direct and indirect drivers of change. The provisioning services, according to the local's experiences were increasingly endangered due to intensifying urban land use and resource use patterns. Land use changes and over-exploitation affected the different provisioning services because of combined effects of demographic, socioeconomic, and effects of science and technology (e.g., increased residential areas, water pollution from household and industrial wastes, increased cultured fisheries that degrade natural fishing grounds). Although climatic variation, invasive species, and not adapted management were mentioned to degrade a lower number of provisioning services, but these can affect vital provisioning services (e.g., climatic variation affects crop production) and can affect locals' wellbeing profoundly.

Our study is especially useful to draw attention to reduce further deterioration of landscapes that provide multiple provisioning services at the village level. This study can be synchronized with studies that show future projections of continued urban expansions around the Laguna Lake and loss of biodiversity $[64,65]$. This study also shows that local landscapes are important resources for continued livelihood support. Studies that systematize local's perception-based knowledge about provisioning services can play a significant role in a better urban and peri-urban land use planning and sustainable development.

Author Contributions: Conceptualization, S.C. and R.A.; methodology, S.C., R.A.; writing S.C., R.A., and R.R.; writing-review and Editing, S.C., R.A., R.R., H.V.T.M.

Funding: This research received no external funding.

Acknowledgments: The open access fee was supported by the generous support The Hosei Society of Sustainability Studies. The first author is grateful to the Japan Society for Promotion of Science (JSPS) for post-doctoral fellowship for support during the fieldwork phase. The authors would like to thank Crisanto Regadio, and Melvin Jabar of De La Salle University for their help in data gathering. The authors would also like to acknowledge their colleagues and community people of Jala-Jala for useful discussion during this study.

Conflicts of Interest: The authors declare no conflict of interest.

\section{References}

1. Haines-Young, R.; Potschin, M. The links between biodiversity, ecosystem services and human well-being. Ecosyst. Ecol. New Synth. 2010, 1, 110-139.

2. Avtar, R.; Suzuki, R.; Sawada, H. Natural Forest Biomass Estimation Based on Plantation Information Using PALSAR Data. PLoS ONE 2014, 9, e86121. [CrossRef] [PubMed]

3. Dawson, N.; Martin, A. Assessing the contribution of ecosystem services to human wellbeing: A disaggregated study in western Rwanda. Ecol. Econ. 2015, 117, 62-72. [CrossRef]

4. Avtar, R.; Kharrazi, A. Exploring Renewable Energy Resources Using Remote Sensing and GIS—A Review. Resources 2019, 8, 149. [CrossRef]

5. Jax, K.; Barton, D.N.; Chan, K.M.; De Groot, R.; Doyle, U.; Eser, U.; Görg, C.; Gómez-Baggethun, E.; Griewald, Y.; Haber, W. Ecosystem services and ethics. Ecol. Econ. 2013, 93, 260-268. [CrossRef]

6. Gómez-Baggethun, E.; Barton, D.N. Classifying and valuing ecosystem services for urban planning. Ecol. Econ. 2013, 86, 235-245. [CrossRef]

7. Avtar, R.; Kumar, P.; Oono, A.; Saraswat, C.; Dorji, S.; Hlaing, Z. Potential application of remote sensing in monitoring ecosystem services of forests, mangroves and urban areas. Geocarto Int. 2016, 32, 874-885. [CrossRef]

8. United Nations Department of Economic and Social Affairs. Available online: https://www.un.org/ development/desa/en/news/population/2018-revision-of-world-urbanization-prospects.html (accessed on 30 September 2019).

9. Venter, O.; Sanderson, E.W.; Magrach, A.; Allan, J.R.; Beher, J.; Jones, K.R.; Possingham, H.P.; Laurance, W.F.; Wood, P.; Fekete, B.M. Sixteen years of change in the global terrestrial human footprint and implications for biodiversity conservation. Nat. Commun. 2016, 7, 12558. [CrossRef] 
10. Marrero, M.; Puerto, M.; Rivero-Camacho, C.; Freire-Guerrero, A.; Solís-Guzmán, J. Assessing the economic impact and ecological footprint of construction and demolition waste during the urbanization of rural land. Resour. Conserv. Recycl. 2017, 117, 160-174. [CrossRef]

11. Sukhdev, P.; Wittmer, H.; Schröter-Schlaack, C.; Nesshöver, C.; Bishop, J.; Brink, P.T.; Gundimeda, H.; Kumar, P.; Simmons, B. The Economics of Ecosystems and Biodiversity: Mainstreaming the Economics of Nature: A Synthesis of the Approach, Conclusions and Recommendations of TEEB; UNEP: Ginebra, Switzerland, 2010; ISBN 3-9813410-3-1.

12. Ramaiah, M.; Avtar, R. Urban Green Spaces and Their Need in Cities of Rapidly Urbanizing India: A Review. Urban Sci. 2019, 3, 94. [CrossRef]

13. Assessment, M.E. Ecosystems and Human Well-Being; Island Press: Washington, DC, USA, 2005; Volume 5.

14. Díaz, S.; Demissew, S.; Carabias, J.; Joly, C.; Lonsdale, M.; Ash, N.; Larigauderie, A.; Adhikari, J.R.; Arico, S.; Báldi, A. The IPBES Conceptual Framework-Connecting nature and people. Curr. Opin. Environ. Sustain. 2015, 14, 1-16. [CrossRef]

15. Douglas, I. Environmental Change in Peri-Urban Areas and Human and Ecosystem Health. Geogr. Compass 2008, 2, 1095-1137. [CrossRef]

16. Livesley, S.; Escobedo, F.; Morgenroth, J. The biodiversity of urban and peri-urban forests and the diverse ecosystem services they provide as socio-ecological systems. Forests 2016, 7, 291. [CrossRef]

17. De Bon, H.; Parrot, L.; Moustier, P. Sustainable urban agriculture in developing countries. A review. Agron. Sustain. Dev. 2010, 30, 21-32. [CrossRef]

18. Avtar, R.; Tripathi, S.; Kumar Aggarwal, A.; Kumar, P. Population-Urbanization-Energy Nexus: A Review. Resources 2019, 8, 136. [CrossRef]

19. Nagendra, H.; Elinor, O. Applying the social-ecological system framework to the diagnosis of urban lake commons in Bangalore, India. Ecol. Soc. 2014, 19, 1-18. [CrossRef]

20. Torres-Lima, P.; Pinel, S.L.; Conway-Gómez, K. Adaptive Governance for Resilience of Peri-Urban Socioecological Systems. In Urban Resilience for Risk and Adaptation Governance; Springer: Cham, Switzerland, 2019; pp. 43-58.

21. Bernholt, H.; Kehlenbeck, K.; Gebauer, J.; Buerkert, A. Plant species richness and diversity in urban and peri-urban gardens of Niamey, Niger. Agrofor. Syst. 2009, 77, 159. [CrossRef]

22. Nfotabong-Atheull, A.; Din, N.; Koum, L.G.E.; Satyanarayana, B.; Koedam, N.; Dahdouh-Guebas, F. Assessing forest products usage and local residents' perception of environmental changes in peri-urban and rural mangroves of Cameroon, Central Africa. J. Ethnobiol. Ethnomedicine 2011, 7, 41. [CrossRef]

23. Vejre, H.; Jensen, F.S.; Thorsen, B.J. Demonstrating the importance of intangible ecosystem services from peri-urban landscapes. Ecol. Complex. 2010, 7, 338-348. [CrossRef]

24. Zasada, I. Multifunctional peri-urban agriculture-A review of societal demands and the provision of goods and services by farming. Land Use Policy 2011, 28, 639-648. [CrossRef]

25. ESPA. Ecosystem Services for Poverty Alleviation. Available online: https://www.espa.ac.uk/ (accessed on 30 September 2019).

26. Ernstson, H. The social production of ecosystem services: A framework for studying environmental justice and ecological complexity in urbanized landscapes. Landsc. Urban Plan. 2013, 109, 7-17. [CrossRef]

27. Pascual, U.; Balvanera, P.; Díaz, S.; Pataki, G.; Roth, E.; Stenseke, M.; Watson, R.T.; Dessane, E.B.; Islar, M.; Kelemen, E. Valuing nature's contributions to people: The IPBES approach. Curr. Opin. Environ. Sustain. 2017, 26, 7-16. [CrossRef]

28. Bennett, E.M.; Cramer, W.; Begossi, A.; Cundill, G.; Díaz, S.; Egoh, B.N.; Geijzendorffer, I.R.; Krug, C.B.; Lavorel, S.; Lazos, E. Linking biodiversity, ecosystem services, and human well-being: Three challenges for designing research for sustainability. Curr. Opin. Environ. Sustain. 2015, 14, 76-85. [CrossRef]

29. Avtar, R.; Tripathi, S.; Aggarwal, K.A. Assessment of Energy-Population-Urbanization Nexus with Changing Energy Industry Scenario in India. Land 2019, 8, 124. [CrossRef]

30. Avtar, R.; Tsusaka, K.; Herath, S. REDD+ Implementation in Community-Based Muyong Forest Management in Ifugao, Philippines. Land 2019, 8, 164. [CrossRef]

31. Chan, K.M.; Goldstein, J.; Satterfield, T.; Hannahs, N.; Kikiloi, K.; Naidoo, R.; Vadeboncoeur, N.; Woodside, U. Cultural services and non-use values. In Natural Capital: Theory and Practice of Mapping Ecosystem Services; Oxford University Press: New York, NY, USA, 2011; pp. 206-228. 
32. Bateman, I.J.; Mace, G.M.; Fezzi, C.; Atkinson, G.; Turner, K. Economic analysis for ecosystem service assessments. Environ. Resour. Econ. 2011, 48, 177-218. [CrossRef]

33. Hara, Y.; Yamaji, K.; Yokota, S.; Thaitakoo, D.; Sampei, Y. Dynamic wetland mosaic environments and Asian openbill habitat creation in peri-urban Bangkok. Urban Ecosyst. 2018, 21, 305-322. [CrossRef]

34. Lee, R.H.; Cheung, K.; Fellowes, J.R.; Guenard, B. Insights Into the Chinese Pangolin's (Manis pentadactyla) Diet in a Peri-Urban Habitat: A Case Study From Hong Kong. Trop. Conserv. Sci. 2017, 10, 1940082917709648. [CrossRef]

35. Kumar, A. Ethno-Botanical Diversity and Conservation Status of Medicinal Flora at High Terrains of Garhwal (Uttarakhand) Himalaya, India: A Case Study in Context to Multifarious Tourism Growth and Peri-Urban Encroachments. World Acad. Sci. Eng. Technol. Int. J. Biol. Biomol. Agric. Food Biotechnol. Eng. 2017, 11, 361-366.

36. Walters, G.; Ndjabounda, E.N.; Ikabanga, D.; Biteau, J.P.; Hymas, O.; White, L.; Obiang, A.-M.N.; Ondo, P.N.; Jeffery, K.J.; Lachenaud, O. Peri-urban conservation in the Mondah forest of Libreville, Gabon: Red List assessments of endemic plant species, and avoiding protected area downsizing. Oryx 2016, 50, 419-430. [CrossRef]

37. Nardi, M.; Lira-Guedes, A.C.; Cunha, A.; Ferreira, H.; Guedes, M.C.; Mustin, K.; Gomes, S.C.P. Artisanal extraction and traditional knowledge associated with medicinal use of crabwood oil (Carapa guianensis Aublet.) in a Peri-Urban Várzea environment in the Amazon estuary. Evid.-Based Complement. Altern. Med. 2016, 2016, 5828021. [CrossRef] [PubMed]

38. Peroni, N.; Hanazaki, N.; Begossi, A.; Zuchiwschi, E.; Lacerda, V.D.; Miranda, T.M. Homegardens in a micro-regional scale: Contributions to agrobiodiversity conservation in an urban-rural context. Ethnobiol. Conserv. 2016, 5, 1-17. [CrossRef]

39. Pauchard, A.; Aguayo, M.; Peña, E.; Urrutia, R. Multiple effects of urbanization on the biodiversity of developing countries: The case of a fast-growing metropolitan area (Concepción, Chile). Biol. Conserv. 2006, 127, 272-281. [CrossRef]

40. Su, S.; Xiao, R.; Jiang, Z.; Zhang, Y. Characterizing landscape pattern and ecosystem service value changes for urbanization impacts at an eco-regional scale. Appl. Geogr. 2012, 34, 295-305. [CrossRef]

41. Austin, Z.; McVittie, A.; McCracken, D.; Moxey, A.; Moran, D.; White, P.C. The co-benefits of biodiversity conservation programmes on wider ecosystem services. Ecosyst. Serv. 2016, 20, 37-43. [CrossRef]

42. Douglas, I. Peri-urban ecosystems and societies: Transitional zones and contrasting values. In The Peri-Urban Interface; Routledge: New York, NY, USA, 2012; pp. 41-52.

43. Tekken, V.; Spangenberg, J.H.; Burkhard, B.; Escalada, M.; Stoll-Kleemann, S.; Truong, D.T.; Settele, J. “Things are different now": Farmer perceptions of cultural ecosystem services of traditional rice landscapes in Vietnam and the Philippines. Ecosyst. Serv. 2017, 25, 153-166. [CrossRef]

44. Tilliger, B.; Rodríguez-Labajos, B.; Bustamante, J.; Settele, J. Disentangling values in the interrelations between cultural ecosystem services and landscape conservation-A case study of the Ifugao Rice Terraces in the Philippines. Land 2015, 4, 888-913. [CrossRef]

45. Settele, J.; Spangenberg, J.H.; Heong, K.L.; Burkhard, B.; Bustamante, J.V.; Cabbigat, J.; Van Chien, H.; Escalada, M.; Grescho, V.; Harpke, A. Agricultural landscapes and ecosystem services in South-East Asia-The LEGATO-Project. Basic Appl. Ecol. 2015, 8, 661-664. [CrossRef]

46. Thompson, B.S.; Primavera, J.H.; Friess, D.A. Governance and implementation challenges for mangrove forest Payments for Ecosystem Services (PES): Empirical evidence from the Philippines. Ecosyst. Serv. 2017, 23, 146-155. [CrossRef]

47. Thompson, B.S.; Clubbe, C.P.; Primavera, J.H.; Curnick, D.; Koldewey, H.J. Locally assessing the economic viability of blue carbon: A case study from Panay Island, the Philippines. Ecosyst. Serv. 2014, 8, 128-140. [CrossRef]

48. Leimona, B.; van Noordwijk, M.; de Groot, R.; Leemans, R. Fairly efficient, efficiently fair: Lessons from designing and testing payment schemes for ecosystem services in Asia. Ecosyst. Serv. 2015, 12, 16-28. [CrossRef]

49. Estoque, R.C.; Murayama, Y. Landscape pattern and ecosystem service value changes: Implications for environmental sustainability planning for the rapidly urbanizing summer capital of the Philippines. Landsc. Urban Plan. 2013, 116, 60-72. [CrossRef] 
50. Santos-Borja, A.; Nepomuceno, D. Laguna de bay: Experience and lessons learned brief. World Lake Database 2006, 15, 225-258.

51. Tamayo-Zafaralla, M.; Santos, R.; Orozco, R.; Elegado, G. The ecological status of lake Laguna de Bay, philippines. Aquat. Ecosyst. Health Manag. 2002, 5, 127-138. [CrossRef]

52. Aquino, L.M.G.; Tango, J.M.; Canoy, R.J.C.; Fontanilla, I.K.C.; Basiao, Z.U.; Ong, P.S.; Quilang, J.P. DNA barcoding of fishes of Laguna de Bay, Philippines. Mitochondrial DNA 2011, 22, 143-153. [CrossRef] [PubMed]

53. Lasco, R.D.; Espaldon, M.V.O.E.; Tapia, M.A. Ecosystems and People: The Philippine Millennium Ecosystem Assessment (MA) Sub-Global Assessment: Synthesis Report; Environmental Forestry Programme, College of Forestry and Natural Resources: Los Baños, the Philippines, 2005.

54. Laguna Lake Development Authority Hydrological Map. Available online: http://llda.gov.ph/hydrologicalmap/ (accessed on 9 November 2019).

55. Yasuto, T.; Ross, J.; Keizrul, A.; Mohd, N.b.M. Catalogue of Rivers for Southeast Asia and the Pacific. Available online: http://hywr.kuciv.kyoto-u.ac.jp/ihp/riverCatalogue/Vol_05/index.html (accessed on 1 September 2019).

56. Chokkalingam, U. One Century of Forest Rehabilitation in the Philippines; CIFOR: Bogor, Indonesia, 2006; ISBN 979-24-4643-5.

57. Lasco, R.; Visco, R.; Pulhin, J. Secondary forests in the Philippines: Formation and transformation in the 20th century. J. Trop. Forest Sci. 2001, 13, 652-670.

58. Chakraborty, S. Watershed Based Analysis of Land Use Change in Laguna Lake Basin in the Philippines: Case Study from San Cristobal Micro-Watershed. Ph.D. Thesis, Ritsumeikan Asia Pacific University, Oita, Japan, 2011.

59. Philippines Statistics Authority Population of Region IV-A-CALABARZON (Based on the 2015 Census of Population). Available online: https://psa.gov.ph/content/population-region-iv-calabarzon-based-2015census-population (accessed on 20 January 2017).

60. Hendriks, V.M.; Blanken, P.; Adriaans, N.F.P.; Hartnoll, R. Snowball Sampling: A Pilot Study on Cocaine Use; IVO, Instituut voor Verslavingsonderzoek, Erasmus Universiteit Rotterdam: Rotterdam, Netherlands, 1992; ISBN 90-74234-02-X.

61. Russell, H.R. Research Methods in Anthropology: Qualitative and Quantitative Approaches; Lanham: Altamira, Spain, 2002; ISBN 0-7591-0148-5.

62. Haines-Young, R.; Potschin, M. Common international classification of ecosystem services (CICES, Version 4.1). Eur. Environ. Agency 2012, 33, 107.

63. Alley, W.M. Ground Water. In Encyclopedia of Inland Waters; Likens, G.E., Ed.; Academic Press: Oxford, UK, 2009; pp. 684-690. ISBN 978-0-12-370626-3.

64. Nor, A.N.M.; Corstanje, R.; Harris, J.A.; Grafius, D.R.; Siriwardena, G.M. Ecological connectivity networks in rapidly expanding cities. Heliyon 2017, 3, e00325. [CrossRef]

65. Iizuka, K.; Johnson, B.A.; Onishi, A.; Magcale-Macandog, D.B.; Endo, I.; Bragais, M. Modeling future urban sprawl and landscape change in the Laguna de Bay Area, Philippines. Land 2017, 6, 26. [CrossRef]

66. Carrus, G.; Scopelliti, M.; Lafortezza, R.; Colangelo, G.; Ferrini, F.; Salbitano, F.; Agrimi, M.; Portoghesi, L.; Semenzato, P.; Sanesi, G. Go greener, feel better? The positive effects of biodiversity on the well-being of individuals visiting urban and peri-urban green areas. Landsc. Urban Plan. 2015, 134, 221-228. [CrossRef]

67. Roussel, F.; Schulp, C.J.; Verburg, P.H.; van Teeffelen, A.J. Testing the applicability of ecosystem services mapping methods for peri-urban contexts: A case study for Paris. Ecol. Indic. 2017, 83, 504-514. [CrossRef]

68. Borelli, S.; Conigliaro, M.; Quaglia, S.; Salbitano, F. Urban and Peri-urban Agroforestry as Multifunctional Land Use. In Agroforestry; Springer: Singapore, 2017; pp. 705-724.

69. McGregor, D.; Simon, D.; Thompson, D. Peri-Urban Ecosystems and Societies: Transitional Zones and Contrasting Values; Earthscan: London, UK, 2006.

70. McDonald, R.I.; Marcotullio, P.J.; Güneralp, B. Urbanization and global trends in biodiversity and ecosystem services. In Urbanization, Biodiversity and Ecosystem Services: Challenges and Opportunities; Springer: Dordrecht, The Netherlands, 2013; pp. 31-52.

71. Philstar Rare Wild Boar Threatened. Available online: https://www.philstar.com/headlines/2008/09/26/403070/ rare-wild-boar-threatened (accessed on 20 January 2017).

72. Erős, T.; Olden, J.D.; Schick, R.S.; Schmera, D.; Fortin, M.-J. Characterizing connectivity relationships in freshwaters using patch-based graphs. Landsc. Ecol. 2012, 27, 303-317. [CrossRef] 
73. Segurado, P.; Branco, P.; Ferreira, M.T. Prioritizing restoration of structural connectivity in rivers: A graph based approach. Landsc. Ecol. 2013, 28, 1231-1238. [CrossRef]

74. Cote, D.; Kehler, D.G.; Bourne, C.; Wiersma, Y.F. A new measure of longitudinal connectivity for stream networks. Landsc. Ecol. 2009, 24, 101-113. [CrossRef]

75. Ward, J. The four-dimensional nature of lotic ecosystems. J. N. Am. Benthol. Soc. 1989, 8, 2-8. [CrossRef]

76. Angela, C.-B.; Javier, C.-J.; Teresa, G.-M.; Marisa, M.-H. Hydrological evaluation of a peri-urban stream and its impact on ecosystem services potential. Glob. Ecol. Conserv. 2015, 3, 628-644. [CrossRef]

77. Lytle, D.A.; Poff, N.L. Adaptation to natural flow regimes. Trends Ecol. Evol. 2004, 19, 94-100. [CrossRef]

78. Ward, J.V. An expansive perspective of riverine landscapes: Pattern and process across scales. GAIA-Ecol. Perspect. Sci. Soc. 1997, 6, 52-60. [CrossRef]

79. Beveridge, M.C.; Ross, L.G.; Kelly, L.A. Aquaculture and biodiversity. Ambio 1994, 23, 497-502.

80. Peng, Y.; Jian, Y.; Wang, J.; Ni, L. A comparative study on aquatic plant diversity in five largest lakes of Hubei Province in China. Acta Hydrobiol. Sin. 2004, 28, 464-470.

81. Karki, M.; Sellamuttu, S.S.; Okayasu, S.; Suzuki, W.; Acosta, L.A.; Alhafedh, Y.; Anticamara, J.A.; Ausseil, A.-G.; Davies, K.; Gasparatos, A. The Regional Assessment Report on Biodiversity and Ecosystem Services for Asia and the Pacific: Summary for Policymaker; Intergovernmental Science-Policy Platform on Biodiversity and Ecosystem Services (IPBES): Bonn, Germany, 2018.

82. NEA, U. The UK National Ecosystem Assessment Follow-on: Synthesis of the Key Findings; UNEP-WCMC: Lwec, UK, 2014.

83. Lopes, R.; Videira, N. A collaborative approach for scoping ecosystem services with stakeholders: The case of Arrabida Natural Park. Environ. Manag. 2016, 58, 323-342. [CrossRef] [PubMed]

84. Swift, M.J.; Izac, A.-M.; van Noordwijk, M. Biodiversity and ecosystem services in agricultural landscapes-Are we asking the right questions? Agric. Ecosyst. Environ. 2004, 104, 113-134. [CrossRef]

(C) 2019 by the authors. Licensee MDPI, Basel, Switzerland. This article is an open access article distributed under the terms and conditions of the Creative Commons Attribution (CC BY) license (http://creativecommons.org/licenses/by/4.0/). 